\title{
Forum
}

\section{If biodiversity offsets are a dead end for conservation, what is the live wire? A response to Apostolopoulou \& Adams}

\author{
Jessica Dempsey and Rosemary-Claire Collard
}

E cofeminist Maria Mies describes capitalist social relations as an iceberg. The visible tip represents the formal economy, where capitalist value emerges from exploited waged labourers and the circulation of monetized goods and assets. Underneath the waterline lurks the rest of the iceberg, and its size dwarfs the tip. Here, Mies points to a much larger world of exploitation on which commodity production and profit-making depend: women, colonies and, at the very base, nature. The bodies, places and materials of the submerged, invisible iceberg supply unwaged labour and unpriced inputs and energies that are productive; capitalism depends on this deeply undervalued work. Let us restate: capitalism exploits, yes, but strangely, it is a mode of organizing society that also relies on this exploitation. As Mies ([1986]1998, p. 200) writes, 'the exploitation of colonies, as well as that of women and other non-wage workers, is absolutely crucial to the capitalist accumulation process'; this exploitation 'constitutes the eternal basis for capitalist accumulation' (Mies, 2007, p. 269).

The environmental movement in all its varied shapes and sizes might be understood as attempting to make visible this simultaneous exploitation of and dependence on the invisible contributions of nature, not only for the sake of saving capitalism but also for saving ourselves. It is not an easy task, no matter what your politics or orientation, radical left to neoliberal conservative. We are surrounded by institutions and policies (laws, tax systems, subsidies) that keep nature in the iceberg under the waterline: cheap or even free. Those who could lose if nature becomes more expensive hold tremendous financial and political capital, capital that has been accumulated through using and tapping into nature's energies and materials over tens and sometimes hundreds of years. Exploiting nature while denying our reliance on it is baked into political and economic systems that hold enormous power asymmetries.

JessiCa DEMPSEy (Corresponding author) Department of Geography, University of British Columbia, 8166, Vancouver, British Columbia, Canada

E-mail jessica.dempsey@geog.ubc.ca

Rosemary-Claire Collard Department of Geography, Concordia University, Montreal, Quebec, Canada

Received 24 June 2016. Revision requested 27 June 2016.

Accepted 29 June 2016. First published online 18 October 2016.
Drawing attention to the crucial work of nature in such a system is a huge challenge. This was evident at a recent negotiation of the Convention on Biological Diversity (CBD) in Montreal, where the policy conversation pivoted towards implementation of the CBD and jump starting progress towards the Aichi biodiversity targets (First meeting of the Subsidiary Body on Implementation, Montreal Canada, 26 May 2016). The 194 Parties to the CBD spent the week considering how national governments could mainstream biodiversity; i.e. infuse it within the policies not only of the Ministry of Environment, but also of Finance, Agriculture, Forestry, Economic Development, and others. There was widespread realization that some of the targets will be hard to achieve, especially those related to the drivers of biodiversity loss: such as Aichi target 3 that asks governments to eliminate perverse subsidies. It seems difficult, or perhaps impossible, to mainstream biodiversity within short-term political cycles struggling with entrenched economic interests in often debt-burdened and austerity bound countries.

Regrettably, we can expect that as the mainstreaming of conservation rolls on, some in the conservation community will call for the expansion of biodiversity offsetting. Offsetting is one approach to conservation and development: it aims to reduce the impact of biodiversity loss by requiring proponents to make up losses elsewhere. While we only heard offsets mentioned once in the plenary in Montreal (by Ghana), there is no doubt they are firmly part of the biodiversity policy terrain. IUCN members will vote on a policy resolution on offsets at the World Conservation Congress in Hawaii in September, 2016 (IUCN, 2016).

Contributing to this unfolding conversation, Apostolopoulou \& Adams (2015a) ask us to consider the effects of offsetting beyond the technical question-'does it work or not' (is biodiversity here the same as restored or protected biodiversity over there?). They ask us to think through how offsetting might be reframing conservation politics. Their intervention raises a number of important points; here we are most interested in their claim that offsets weaken conservation.

In a time when conservation is trying to mainstream biodiversity into development, Apostolopoulou \& Adams express what might seem like a strange concern: offsetting, they suggest, dissolves what they see as an important tension between conservation and development. For them, offsetting 
folds conservation too far into economic development, smoothing the way for new industrial scale projects such as mines. As an approach to conservation, offsetting weakens it by separating it from the very environmental and social struggles that aim 'to prevent the further degradation of ecosystems' (2015a, p. 6). Even further, Apostolopoulou \& Adams argue offsetting moves our political imagination away from challenging 'the drivers of environmental destruction', foreclosing 'critique of the current political and economic context' (2015a, p. 5). In other words, offsets cement business as usual political economic relationships.

Our response is not so much a critical review; rather we build on Apostolopoulou \& Adams's view by opening windows onto the preferred political approaches that remain tacit in their paper. What are these other conservation politics obfuscated by offsets? We begin this response with Maria Mies because we've found her feminist approach helpful in articulating a reading of capitalist and environmental crises, a reading that we think gestures towards politics that have more of a chance to break the monoculturing of the planet (see also Collard et al., 2015).

\section{What is the problem, anyway?}

One reading of environmental crises such as extinction frames the political problem we face as one of choosing between various trade-offs: trade-offs between conservation and development, between different human needs or values, or perhaps between different ecosystem services. The gamble that offset proponents are making is that universalizing offsets in national systems and corporate practices throughout the world will help soothe these fundamental tensions, bringing green development via mainstreaming biodiversity conservation. But instead of a world pock-marked with unfortunate trade-offs (that can only be offset), we could understand these so-called trade-offs as symptoms of a deeply contradictory political economic system.

One of the most fundamental contradictions is between capitalism's exploitation of nature and its dependence on it. As Mies's iceberg reminds us, capital accumulation requires natures-especially 'cheap natures' (Moore, 2015, p. 17) - but these natures tend to get used up, spat out and degraded in the process. Capitalism tends to erode its conditions of possibility (O'Connor, 1988); i.e. all the energies and materials of the underwater portion of the iceberg. More specifically, states and firms rely upon expanded development to create further growth and avoid economic decline or crisis, yet this expanded development undermines the very conditions of production needed for this growth. A capitalist system can only ever produce trade-offs because capital accumulation depends on uneven valuation: on valuing some people, places, species and labours less than others, and on exploiting these undervalued things. Instead of a politics organized around choosing between trade-offs, political economists like Mies ask us to understand human and non-human injustices as connected through capitalist value production, through 'vast chains of accumulation' (Robbins, 2014, p. 233). Framed this way, biodiversity loss and the devaluation of often raced, classed and gendered bodies are not to be understood as trade-offs to be managed, nor as things to be offset, but rather as embedded within global capitalism as we know it.

Organized and fierce groups of people throughout the world have chipped away at these devaluations on which capital relies, changing the nature of capitalism as we know it by altering power relations. This includes labour unions, feminist movements of all kinds, indigenous struggles for land and rights, and of course, environmental movements. Some of the latter have led to new laws and policies: endangered species legislation, environmental and social impact assessment, wildlife laws, protected areas and pollution and waste standards. But such environmental protections are not removed from human violence, either. Consider the staggering number of people evicted from protected areas, estimated at 8.5 million (cited in $\mathrm{Li}, 2010$ ). These evictions are highly raced, classed and geographically uneven, disproportionately affecting those in the global South, and indigenous peoples and ethnic minorities, who have their own ways of living with and co-producing diverse natures.

Going back to Mies's iceberg, what these human exclusions from protected areas tell us is that environmental laws and policies often shift the burden elsewhere in the underwater iceberg: we might conserve some parts of nature here or there but the burden is displaced onto other bodies and places, ones Klein (2014) calls sacrifice zones. These are places and bodies that count a little bit less than others: they can be poisoned, drained or destroyed for the supposed greater good of progress. In order to have sacrifice zones you also have to have people and cultures that are available to be eroded: people and cultures that count a little less. Imagine, perhaps, an endless game of hot potato where the burning hot problem is thrown around the circle, over and over again.

This problem is not confined to conservation. Pulido (1994) documents cases of late-2oth century environmental justice activism to show how some significant local victories (e.g. more stringent air quality regulation in southern California) can have the effect of merely shifting the problem elsewhere. In the case of California, polluting factories moved across the border to Mexico, where regulation was less strictly enforced. For Pulido (op. cit.), this means environmental justice activists need to form solidarities across borders, forming an international movement powerful enough to match international capital.

In sum, as we see it, conservation faces two major challenges. The first challenge is to end the exploitation of nature in a system built upon nature's exploitation. The second challenge is to address the exploitation of and 
violence against spaces and species under the waterline without sacrificing others who are also underwater. Offsets respond to neither of these twin challenges. They stay trapped in trade-off politics, and are incapable of tackling global connections between people, places and natures in the underwater portion of the iceberg.

So, we wonder: if offsets are a dead end for conservation politics, what is the live wire? Although left implicit, Apostolopoulou \& Adams seem to be seeking more opposition to accumulated forms of capital: monetary but also political and knowledge capital. They are looking for a fierce oppositional or perhaps solidarity politics that can also chip away at global political economic processes that create the conditions for more people and places to be designated as cheap and exploitable over and over again. They want more movements capable of disrupting the iceberg of exploitations that Mies captures so well, rather than offsets that entrench the status quo.

Could biodiversity conservation become an international movement capable of challenging international capital, which remains stubbornly lodged in some places and bodies and not others. Can it become a potent force for challenging what Mies ([1986]1998, p. 77) calls the 'underground connections' between bodies and lives in the submerged part of the iceberg?

\section{From rights to justice to non-sacrificial politics}

Conservation NGOs and institutions have come a long way in recognizing the movement's historical violences: it is now practically axiomatic that conservation organizations and policies must respect the rights of indigenous peoples and local communities, as well as consider who bears the brunt of conservation policies and interventions, and mitigate for those costs. Overall, this reflects a turn to a kind of distributive justice in conservation, meaning a focus on material 'who gets what'. Others push for more emphasis on procedural justice, arguing that conservation must also consider questions of who participates and whose knowledge and ontologies are recognized as legitimate or not (Martin et al., 2013; Forsyth, 2014). A kind of just conservation, then, must be about distribution and access of land and resources, but also about challenging racist discourses about indigenous peoples, farmers and pastoralists as being 'irrational and environmentally destructive' (Upton, 2014, p. 211).

Yet an emphasis on respecting rights, and procedures, as well as growing recognition of diverse knowledges and world-views in conservation (perhaps similar to what others have termed 'inclusive conservation'; Tallis et al., 2014) can only go so far. Manifesting rights and diverse values on the ground tends to involve hard-fought struggles against systemic, historical patterns that allow some voices and values to be continually valued more than others. When
Apostolopoulou \& Adams worry about dissolving the line between conservation and development, we think they are calling for the conservation movement to be more willing to pick sides, to focus a little bit less on improving or offsetting the practices of firms like Rio Tinto, and more on joining local communities and movements who oppose developments or demand more benefits from bearing the burdens and vulnerabilities of say, a new mining development. For Apostolopoulou \& Adams, and we agree, creating the conditions for diverse, thriving human and non-human bodies, communities and ways of living requires healthy doses of antagonistic, organized political movements able to defeat or at least reconfigure powerful state and corporate actors.

One doesn't need to look far to find these movements, all over the world: for example, in the Environmental Justice Atlas (Temper et al., 2015) there are 1,774 cases of struggles worldwide, including struggles against hydroelectric development and extraction projects, deforestation, land grabs, and many more.

But there are limits to focusing on separate battles fought community by community, development by development, monoculture by monoculture. As Pulido (1994) reminds us, the effect of a victory in one place can displace the problem to another place. So what about the global processes (manifest in institutions, agreements, economic flows) that link different bodies up in times and places and that continually place certain bodies in vulnerable conditions? This is where politics may need to get 'structural'. As Apostolopoulou \& Adams write elsewhere, 'an important question is whether, in the era of capitalism in crisis, there are potential anticapitalistic elements in emerging conservation struggles' (2015b, p. 30).

The live wire for conservation politics humming in the shadows of Apostolopoulou \& Adams's critique seems to be one that would focus on capitalism's inherent asymmetries: a conservation politics that fights against (or even flips?) Mies's iceberg. This means a conservation politics that refuses to sacrifice human or non-human bodies or spaces in one place in the name of global trickle down development, even green development. A conservation movement that does not shift problems around to other bodies but aims to get at these global connections that continually devalue again and again: North, South and in between. What might this mean for conservation?

\section{Shaming and taming capital}

Conservation could focus on increasing accountability and responsibility for transnational corporations, not only through collaboration or negotiation but also antagonistically and in solidarity with those communities and people who experience harm. For example, Canada, where we are 
from, is home to $75 \%$ of the world's largest exploration and mining companies, and many oil and gas companies, some of which have been accused of serious human rights abuses (e.g. Gordon \& Webber, 2008; Pedersen, 2014). In 2015 the United Nations Human Rights Committee (UN HRC, 2015) called for Canada to investigate and regulate the actions of these Canadian corporations abroad. The Committee also drew attention to domestic human rights failures, including inadequate response to high numbers of missing and murdered indigenous women and gender inequality in general. Canada has so far resisted such calls. There are cases of serious community concern domestically, too: the Attiwapiskat First Nation has been living in a state of emergency in Northern Canada, lacking housing and clean water, and facing a crisis of youth suicides. Meanwhile a multi-million dollar De Beers mine extracts diamonds $90 \mathrm{~km}$ away. Despite ongoing efforts by the First Nation to increase its share of benefits from the mine, including a hunger strike and blockades, the state has been on the side of the mine (Pasternak, 2016). When it comes to the interface between extraction and conservation, there is significant room for conservationists to work in solidarity with communities resisting projects and/or in demanding more benefits from extraction. This is preferable to approaches that facilitate the social license of mining firms to operate, smoothing the pathway for development (i.e. De Beers lists its participation in Business and Biodiversity Offsets Programme events in its 2014 annual report).

Conservation groups could also become more vocal and active in campaign finance and lobby reform efforts to lessen the influence that extractive, agricultural and forest companies have with governments of any stripe. In Canada one environmental group, the Dogwood Initiative, has turned its attention towards the influence of big business and labour in politics with its 'Ban Big Money' campaign (Dogwood, 2016). Could the multi-faceted conservation movement also become a force for reducing the influence of big money and big business in politics?

What if rather than somewhat obsessively trying to improve corporations through round tables, stakeholder forums, and new disclosure reports, conservation organizations developed divestment campaigns against the worst offenders against biodiversity, galvanizing university students on the monoculturing of the planet. The Forest 500 project has already identified and ranked the 250 companies and investors most responsible for deforestation (Global Canopy Programme, 2015). Maybe there is room to pivot this into a second axis of the divestment campaign? While conservation has been working hard to develop close working relationships with the world's largest corporations (MacDonald, 2010), a divestment from deforestation strategy could be a part of shifting the cultural and political-economic winds, just like divestment from fossil fuel campaigns. If it is wrong to profit from wrecking the climate, as the divestment movement says, then it is wrong to profit from monoculturing the planet. Conservation could focus less on building fences to keep people out, and more on disciplining capital and on building ethical and political power: both necessary steps towards creating systemic change. The times seem to call for bigger sticks, not carrots.

\section{Payments for ecological debt, not offsets}

A concern with the above approach might be that it sounds anti-development: against mines, extraction and agriculture, all of which, mainstream thinking goes, are needed on large scales to launch people out of poverty in the socalled Third World. But as decades of critical development scholars have explained, underdevelopment is a state created via imperialism and colonialism: rich countries have accumulated their vast wealth by extracting resources (and disposing waste) beyond their borders, over hundreds of years (Davis, 2001). This means, as Martinez-Alier writes, 'environmental injustices are not only local, they are also global' (2014, p. 241). This conceptualization of the problem suggests a more nuanced solution than simply massive industrial development (although it does not preclude this, either); it suggests redistribution, such as payments for ecological debt. The concept of ecological debt is about showing how value accrued in the Global North has depended inextricably on devaluation in the Global South. It is inherently about linking distant places and rectifying cumulative historical geographical inequalities (Warlenius et al., 2015). Rather than promoting a kind of trickle-down theory of economic green development, payments for ecological debt are based upon redistribution and reparations.

Might conservationists rally around payments for ecological debt rather than payments for ecosystem services? Payments to those conserving biological diversity would thus not be for 'ecological services' produced, but rather be debt payments made by those who have taken up disproportionate space of the global commons. How might such debts be paid? Dawson (2016) provocatively suggests that payments might flow through a guaranteed income supplement for inhabitants of nations who are owed 'biodiversity debt'. Dawson argues that such incomes should flow not through the state, but rather to people directly, given that so many governments are captured by resource extraction interests, and that such direct repayments of debt 'would entitle the indigenous and forest-dwelling peoples who make these zones of rich biodiversity their homes with the economic and political power to push their governments to implement significant conservation measures' (2016, p. 91). Could conservation organizations facilitate not only the development of tourism lodges that compete against each other but be a part of a growing movement of a transnationally organized union of conservation labourers who could collectively demand higher payments for ecological debt? 
We offer up these ideas not because they are silver bullets, holy grails or miracle cures. There are no such things. But we live in a desperate time of countless human and non-human tragedies, on a planet that is less bio-culturally diverse by the year: an earth, as Haraway (2015) writes, 'full of refugees, human and not, without refuge' (p. 160). There have been equally tragic political attempts in response, including what one of us has called a 'tragedy of liberal environmentalism' (Dempsey, 2016). Flying under the tattered sustainable development banners of compromise and pragmatism, liberal environmentalism has been an approach that aims to fix environmental concerns with economic growth (Bernstein, 2002). Liberal environmentalism seeks a smooth space of politics where players find common ground through dialogue and the purportedly neutral signifiers of numbers and money; it aspires to 'liberation by calculation' (Dempsey, 2016, p. 237). This has been a cherished aspiration of many conservationists, and biodiversity offsets are the newest vehicle for this aspiration. Yet liberation by calculation has failed, as measures of escalating biodiversity loss attest. The time has come to change tack. We've made a preliminary stab here at what a different suite of strategies might look like, ones that can facilitate the growth of people's power, capable of really disciplining capital and governments towards a diverse and abundant planet.

\section{Author contributions}

This article is based on JD's research and draws on an ongoing collaboration with RC. JD is the lead author, with contributions from RC.

\section{References}

Apostolopoulou, E. \& Adams, W.M. (2015a) Biodiversity offsetting and conservation: reframing nature to save it. Oryx, dx.doi.org/ 10.1017/Soo30605315000782.

Apostolopoulou, E. \& Adams, W.M. (2015b) Neoliberal capitalism and conservation in the post-crisis era: The dialectics of "green" and "un-green" grabbing in Greece and the UK. Antipode, 47, 15-35.

Bernstein, S. (2002) The Compromise of Liberal Environmentalism. Columbia University Press, New York, USA.

Collard, R.C., Dempsey, J. \& SundberG, J. (2015) A manifesto for abundant futures. Annals of the Association of American Geographers, 105, 322-330.

Davis, M. (2001) Late Victorian Holocausts: El Niño Famines and the Making of the Third World. Verso Books, London, UK.

Dawson, A. (2016) Extinction: A Radical History. OR Books, New York, USA.

DEMPSEY, J. (2016) Enterprising Nature. Wiley-Blackwell, London, UK.

Dogwood (2016) Ban Big Money in B.C. Politics. Http:// banbigmoney.dogwoodbc.ca [accessed 16 August 2016].

Forsyth, T. (2014) Climate justice is not just ice. Geoforum, 54, 230-232.

Global Canopy Programme (2015) Forest 50o. Http://forest50o. org/ [accessed 16 August 2016].
Gordon, T. \& Webber, J. (2008) Imperialism and resistance: Canadian mining companies in Latin America. Third World Quarterly, 29, 63-87.

Haraway, D. (2015) Anthropocene, Capitalocene, Plantationocene, Chthulucene: Making kin. Environmental Humanities, 6, 159-165. IUCN (2016) o64 - IUCN Policy on Biodiversity Offsets. Https:// portals.iucn.org/congress/motion/064 [accessed 16 August 2016].

KLEIN, N. (2014) This Changes Everything: Capitalism vs. the Climate. Simon and Schuster, New York, USA.

LI, T.M. (2010) To make live or let die? Rural dispossession and the protection of surplus populations. Antipode, 41, 66-93.

MacDonald, K.I. (2010) The devil is in the (bio)diversity: private sector "engagement" and the restructuring of biodiversity conservation. Antipode, 42, 513-550.

Martin, A., McGuire, S. \& Sullivan, S. (2013) Global environmental justice and biodiversity conservation. The Geographical Journal, 179, 122-131.

Martinez-Alier, J. (2014) The environmentalism of the poor. Geoforum, 54, 239-241.

Mies, M. ([1986]1998) Patriarchy and Accumulation on a World Scale. Zed Books, London, UK.

Mies, M. (2007) Patriarchy and accumulation on a world scale revisited: keynote lecture at the Green Economics Institute 2005. International Journal of Green Economics, 1, 268-275.

Moore, J. (2015) Capitalism in the Web of Life: Ecology and the Accumulation of Capital. Verso Books, London, UK.

O'Connor, J. (1988) Capitalism, nature, socialism: a theoretical introduction. Capitalism, Nature, Socialism, 1, 11-38.

Pasternak, S. (2016) The fiscal body of sovereignty: to 'make live' in Indian country. Settler Colonial Studies, 6, 317-338.

Pedersen, A. (2014) Landscapes of resistance: community opposition to Canadian mining operations in Guatemala. Journal of Latin American Geography, 13, 187-214.

Pulido, L. (1994) Restructuring and the contraction and expansion of environmental rights in the United States. Environment and Planning A: Society and Space, 26, 915-936.

Robbins, P. (2014) Cries along the chain of accumulation. Geoforum, $54,233-235$.

Tallis, H. \& Lubcheco, J. \& 238 Co-signatories (2014) Working together: a call for inclusive conservation. Nature, 515, 27-28.

Temper, L., Del Bene, D. \& Martinez-Alier, J. (2015) Mapping the frontiers and front lines of global environmental justice: the EJAtlas. Journal of Political Ecology, 22, 255-278.

Upton, C. (2014) The new politics of pastoralism: identity, justice and global activism. Geoforum, 54, 207-216.

United Nations Human Rights Committee (2015) Concluding observations on the sixth periodic report of Canada (August 13 2015). Http://tbinternet.ohchr.org/_layouts/treatybodyexternal/ Download.aspx?symbolno=CCPR\%2fC $\% 2 \mathrm{fCAN} \% 2 \mathrm{fCO} \% 2 \mathrm{f} 6 \&$ Lang=en [accessed 28 June 2016].

Warlenius, R., Pierce, G. \& Ramasar, V. (2015) Reversing the arrow of arrears: the concept of "ecological debt" and its value for environmental justice. Global Environmental Change, 30, 21-30.

\section{Biographical sketches}

Jessica Dempsey researches attempts to monetize biodiversity conservation. Rosemary - Cla IRE COLLARD studies the relationship between capitalism and wildlife, with a focus on the global exotic pet trade. Together, Dempsey and Collard write about the politics and production of capitalist natures. 